\title{
The role of local propolis extract against harmful effects of acrylamide on some male reproductive parameters in rats
}

\author{
A. M. Ghazi H. Kh. Ulaiwi S. H. Jary \\ Coll. of Vet. Med. /Unive. of Al-Qadisiyah.
}

\begin{abstract}
Propolis is a natural resinous substance obtained from bee hives living on various plant sources. The present experiment was designed to investigate the protective role of ethanolic extract of local propolis against the possible reproductive harmful effects induced by acrylamide when administered orally in male rates. A total of Thirty sexually mature male albino rats were randomly divided equally into three different groups $(n=10)$, the first one : served as normal control, the second group received acrylamide alone (150 mg / Kg BW), the third group received acrylamide in same dose and treated with local propolis extract $(200 \mathrm{mg} / \mathrm{Kg} \mathrm{BW})$ twice daily. Doses were given by drenching for four weeks. The result of study revealed that administration of acrylamide induced significant decrease in the sperm concentration, sperm motility, rate of viability and normal sperms as well as decrease in weights of testes, epidydemis ,prostate gland, seminal vesicles, serum testosterone, FSH, LH levels with significant increase in sperm abnormalities compared with control group. Treatment with local propolis extract improved the harmful effects of acrylamide on reproductive parameters in male rats toward the normal values.
\end{abstract}

\section{Introduction}

Infertility is one of the major health problems in life and approximately about $30 \%$ of this problem is due to male factor (1). Acrylamide used in many fields, from industrial manufacturing to laboratory work, is also formed during the heating process through the interactions of amino acids. Therefore , acrylamide poses a significant risk for both human and animal health (2). Acrylamide was shown to be a neurotoxicity (3) reproductive toxicity (4) and carcinogen in animal species ( 5 ).Propolis is a resinous substance derived from the plant resins collected by honeybees. Bees use it as a glue, general-purpose scaler, and draught extruder for beehives. Its color varies from green, red to dark brown (6) Etymologically, the Greek word propolis means pro, for or in defence, and polis, the city, that is "defence of the hive". Bees use it to seal holes in their honeycombs, smooth out internal walls as well as to cover carcasses of intruders who died inside the hive in order to avoid their decomposition. Propolis also protects the colony from diseases because of its antiseptic efficacy and antimicrobial properties (7).Complexity and variety of the chemical composition of propolis has been reported in the literature, From different botanical and geographical origins of world, more than 300 compounds including volatile organic compounds, flavonoid aglycones, phenolic acids and their esters, phenolic aldehydes, alcohols and ketones, sesquiterpenes, quinones, coumarins, steroids, aminoacids were reported to have been isolated from propolis $(8,9)$. Most of the compounds from isolated propolis include the phenolics with important protective effect against oxidation reactions such as those with regular agents like BHT and hydroquinone. Flavones, coumarines, and many other phenolic compounds have reducing activity, hydrogen-donors and metal chelating properties. They are also used as radical quenchers in organic solutions and biological fluids $(10,11)$ They have been used since ancient times as a medicine because of their biological properties as anti- 
inflammatory, anti-allergic properties, anticarcinogenic, anti-oxidative, anti-fungal, anti-viral, immuno-stimulant and for tissue regeneration. $(12,13)$ The use of propolis for various purposes has a long history dating back to at least $300 \mathrm{BC}(14)$ and even now, in the 21 st century, it is used in home remedies and personal products (15) Propolis has also gained popularity in various parts of the world, including the United States, Japan, and the European

\section{Material \& methods}

\section{- Propolis samples :-}

Propolis samples were collected from local beehives of honey bees in Al-Diwanyia city, Iraq during spring and may in 2011. after that, propolis samples were cleaned, free of wax, paint, wood, cut into small pieces, and kept in the dark at $4 \mathrm{c}$ until use.

\section{- Ethanolic extract of propolis :-}

Twenty gram of crude propolis were mixed with $100 \mathrm{ml}$ of ethanol alcohol (70\%) in dark brown bottle for extraction. The mixture was left for 7 days at room temperature and in dark place. the container was shaked 2 or 3 times per day and returned to warm dark place. The mixture was filtered through Whatman No. 1 filter paper. This process was repeated twice. Finally the alcohol was evaporated by oven at $45^{\circ} \mathrm{C}$, then the extract was weighed and stored in dark clean container until use.

\section{Animal design:}

\section{- Animals}

Healthy adult male albino rats of the Wistar strain with proven fertility, 56 months of age and weighing 200-250 g, were supplied from the Animal Breeding House of the Medical college in Al-najaf University, Al-Najaf, Iraq. Animals were housed in plastic cages with standard dimension under controlled temperature $\left(23 \pm 2{ }^{\circ} \mathrm{C}\right), 12$-h light/dark cycle and 60 relative humidity. Water and food were available ad labium. Rats were acclimatized to the laboratory environment for two weeks prior to the start of experiments.
Union, where it is claimed that it improves human health and prevents conditions such as inflammation, heart disease, diabetes and even cancer $(16,17)$ Caffeic acid phenethyl ester (CAPE) is the active component of propolis (18) So the aim of the present study was to evaluate the protective effects of an ethanolic extract of local propolis when administrated orally on the some male reproductive parameters after administration of acrylamide in rats.

\section{- Experimental design}

After the period of acclimation, animals were divided into three equal groups with 10 animals in each group. The first group was used as negative control. The second male group was orally treated with acrylamide $(150 \mathrm{mg} / \mathrm{kg} \mathrm{B.W})$. The third male group was orally treated with propolis $(200 \mathrm{mg} / \mathrm{kg}$ b.w.) twice daily after administration of acrylamide substance orally in the same dose $(150 \mathrm{mg} / \mathrm{kg} \mathrm{B.W})$ The duration of the oral administration during the experiments lasts for 30 day.

\section{- Semen characteristics:}

Seminal content of epididymis was obtained by cutting of cuda epididymis using surgical blades and squeezed in a sterile clean watch glass. This content was diluted 10 times with $2.9 \%$ sodium citrate dehydrate solution and thoroughly mixed to estimate the progressive motility and sperm concentration ( 19). One drop of the suspension was smeared on a glass slide and stained by Eosin-nigrosin stain to determine the percentage of sperm cell viability and morphological abnormalities (20). Abnormal head and tails were evaluated according to (21).

\section{- Reproductive organ weights :}

At the termination of the experiment, reproductive organs which include testes and reproductive accessory organs (epididymis , prostate gland, seminal vesicle) were dissected out, trimmed off the attached 

AL-Qadisiya Journal of Vet.Med.Sci.
Vol./12
No./1

tissue, after that weighed and record their weights.

\section{- Hormones assay :}

After light anesthesia with chloroform , the blood was collected from the retroorbital plexus in a test tube and left to clot then centrifuged. After centrifugation at $3000 \mathrm{rpm}$ for 15 minutes the clear sera were separated for determination of serum levels of testosterone hormone, follicle stimulating hormone (FSH) and Luteinizing hormone (LH) by method mentioned by Teitz (22).

\section{Results}

The result of present study revealed that administration of acrylamide substance orally in dose (150 mg / Kg BW) in male rats induced significant decrease at $(\mathrm{p}<0.05)$ in the sperm characteristics ( sperm concentration, sperm motility, viability , normal sperm ) $(60.02 \pm 0.98,35.90 \pm 1.2$, $0.97 \pm 0.11,37 \pm 1.90$ ) respectively compared with control group ( $89.11 \pm 1.1$, $69.81 \pm 0.62,2.41 \pm 0.17,75.81 \pm 1.32 \quad)$ in the same time induced significant increase at

\section{- Statistical analysis :}

All the grouped data were statistically reading with SPSS program, version 16 software (2009) . Testing methods included one-way analysis of variance (ANOVA) for comparisons between more than two groups followed by least significant difference (LSD) test for comparison between two groups. P-values of $\leq 0.05$ were considered to record statistical significance. All the data were expressed as mean \pm standard error

$(\mathrm{p}<0.05)$ in the sperm abnormalities (12.3 \pm 0.96$)$ compared with control group (5.2 \pm 0.36$)$ while co-administration of local propolis extract to acrylamide treated group rats showed a significant increase in the sperm characteristics toward the control values $\quad(87.71 \pm 1.90,69.30 \pm 0.17$, $2.37 \pm 0.18,74.93 \pm 0.96$ ) and a significant decrease in the sperm abnormalities $(9.1 \pm 0.83)$ compared with acrylamide treated group table (1).

Table (1): effect on the sperm characteristics in negative control, acrylamide, acrylamide \& local propolis extract groups in male rats.

\begin{tabular}{|c|c|c|c|c|c|}
\hline $\begin{array}{c}\text { Animal } \\
\text { Group }\end{array}$ & $\begin{array}{c}\text { concentration } \\
\text { (Million/ml) }\end{array}$ & $\begin{array}{c}\text { Sperm } \\
\text { motility (\%) }\end{array}$ & $\begin{array}{c}\text { Rate of } \\
\text { Viability(\%) }\end{array}$ & $\begin{array}{c}\text { Normal } \\
\text { sperms(\%) }\end{array}$ & $\begin{array}{c}\text { Sperm } \\
\text { Abnormalities }\end{array}$ \\
\hline $\begin{array}{c}\text { Negative } \\
\text { control }\end{array}$ & $\begin{array}{c}89.11 \pm 1.1 \\
\mathrm{~b}\end{array}$ & $69.81 \pm 0.62 \mathrm{~b}$ & $2.41 \pm 0.17 \mathrm{~b}$ & $75.81 \pm 1.32 \mathrm{~b}$ & $\begin{array}{c}5.2 \pm 0.36 \\
\mathrm{~b}\end{array}$ \\
\hline acrylamide & $\begin{array}{c}60.02 \pm 0.98 \\
\mathrm{a}\end{array}$ & $\begin{array}{c}35.90 \pm 1.2 \\
\mathrm{a}\end{array}$ & $0.97 \pm 0.11 \mathrm{a}$ & $\begin{array}{c}37 \pm 1.90 \\
\mathrm{a}\end{array}$ & $\begin{array}{c}12.3 \pm 0.96 \\
\mathrm{a}\end{array}$ \\
\hline $\begin{array}{c}\text { Acrylamide } \\
\text { \& propolis }\end{array}$ & $\begin{array}{c}87.71 \pm 1.90 \\
\mathrm{~b}\end{array}$ & $69.30 \pm 0.17 \mathrm{~b}$ & $2.37 \pm 0.18 \mathrm{~b}$ & $74.93 \pm 0.96 \mathrm{~b}$ & $\begin{array}{c}9.1 \pm 0.83 \\
\mathrm{~b}\end{array}$ \\
\hline
\end{tabular}

- values represent means \pm SE.

- Similar Letters represent no significant differences between the groups at $(\mathrm{P}<0.05)$.

- Different letters represent significant differences between the groups at $(\mathrm{P}<0.05)$.

The result in table (2) showed that administration of acrylamide substance orally in dose (150 mg / Kg BW) in male rats induced significant decrease at $(\mathrm{p}<0.05)$ in the weighs of testes and reproductive accessory organs ( epididymis , prostate gland, seminal vesicle) $(490 \pm 1.7,190 \pm 1.9$, $298 \pm 0.81 \quad, \quad 0.81 \pm 0.03 \quad$ ) respectively compared with control group (582 \pm 0.9 , $230.1 \pm 0.97,463 \pm 0.13,75 \pm 1.9 \quad)$ respectively, in the same time the result of use of local propolis extract for rats treated 

AL-Qadisiya Journal of Vet.Med.Sci.
Vol./12
No./1

with acrylamide as detrimental substance on male reproductive system in rats revealed that there were returned of organs weights to the values near to the control $(580 \pm 0.63$, $227 \pm 0.81 \quad, 460 \pm 0.51 \quad, \quad 72 \pm 0.97$ ) respectively .

Table (2): effect on the male reproductive organs weight (mg /100 gm B.W.) in negative control , acrylamide , acrylamide \& local propolis extract groups in male rats.

\begin{tabular}{|c|c|c|c|c|}
\hline \multirow{2}{*}{ Animal Group } & \multicolumn{4}{|c|}{ Reproductive male organ (gram / 100 gram B.W) } \\
\cline { 2 - 5 } & weight of Testes & $\begin{array}{c}\text { weight of } \\
\text { Epidydemis }\end{array}$ & $\begin{array}{c}\text { Weight of } \\
\text { Prostate gland }\end{array}$ & $\begin{array}{c}\text { Weight of } \\
\text { seminal vesicles }\end{array}$ \\
\hline $\begin{array}{c}\text { Negative } \\
\text { control }\end{array}$ & $582 \pm 0.9 \mathrm{~b}$ & $230.1 \pm 0.97 \mathrm{~b}$ & $463 \pm 0.13 \mathrm{~b}$ & $75 \pm 1.9 \mathrm{~b}$ \\
\hline acrylamide & $490 \pm 1.7 \mathrm{a}$ & $190 \pm 1.9 \mathrm{a}$ & $298 \pm 0.81 \mathrm{a}$ & $50 \pm 1.00 \mathrm{a}$ \\
\hline $\begin{array}{c}\text { Acrylamide \& } \\
\text { propolis }\end{array}$ & $580 \pm 0.63 \mathrm{~b}$ & $227 \pm 0.81 \mathrm{~b}$ & $460 \pm 0.51 \mathrm{~b}$ & $72 \pm 0.97 \mathrm{~b}$ \\
\hline
\end{tabular}

- values represent means \pm SE.

- Similar Letters represent no significant differences between the groups at $(\mathrm{P}<0.05)$.

- Different letters represent significant differences between the groups at $(\mathrm{P}<0.05)$.

The Result in Table (3) showed that administration of acrylamide alone induced significant decrease at $(\mathrm{P}<0.05)$ in the serum hormonal levels ( testosterone , FSH , LH ) $(0.10 \pm 0.03, \quad 0.93 \pm 0.03,0.81 \pm 0.03)$ respectively compared with control group $(0.51 \pm 0.07,1.50 \pm 0.04,1.37 \pm 0.05)$ respectively while co-administration of local propolis extract to acrylamide treated group rats showed significant increase at $(\mathrm{P}<0.05)$ in the hormonal levels near to the control group rats $(0.49 \pm 0.02,1.49 \pm 0.06$, $1.37 \pm 0.08)$. Respectively .

Table (3): effect on the some reproductive hormonal levels in negative control, acrylamide , acrylamide \& local propolis extract groups in male rats.

\begin{tabular}{|c|c|c|c|}
\hline \multirow{2}{*}{ Animal Group } & \multicolumn{2}{|c|}{ Reproductive hormone \& unit of measure } \\
\cline { 2 - 4 } & $\begin{array}{c}\text { Testosterone } \\
\text { (nanograme/ml) }\end{array}$ & FSH(IU/ml) & LH(IU/ml) \\
\hline Negative control & $0.51 \pm 0.07 \mathrm{~b}$ & $1.50 \pm 0.04 \mathrm{~b}$ & $1.37 \pm 0.05 \mathrm{~b}$ \\
\hline acrylamide & $0.10 \pm 0.03 \mathrm{a}$ & $0.93 \pm 0.03 \mathrm{a}$ & $0.81 \pm 0.03 \mathrm{a}$ \\
\hline $\begin{array}{c}\text { Acrylamide \& } \\
\text { propolis }\end{array}$ & $0.49 \pm 0.02 \mathrm{~b}$ & $1.49 \pm 0.06 \mathrm{~b}$ & $1.37 \pm 0.08 \mathrm{~b}$ \\
\hline
\end{tabular}

- values represent means \pm SE.

- Similar Letters represent no significant differences between the groups at $(\mathrm{P}<0.05)$.

- Different letters represent significant differences between the groups at $(\mathrm{P}<0.05)$.

\section{Discussion}

Propolis has attracted researchers' interest in the last decades because of its several biological and pharmacological properties, such as immunomodulatory, 
antitumor, antimicrobial, antiinflammatory, antioxidant, among others (23). Besides, propolis-containing products have been intensely marketed by the pharmaceutical industry and health-food stores (24).propolis rich in variety of biological active substances have highly activity against oxidative stress inducing by free radicals and reactive oxygen spices ( 25 ). Acrylamide is an important industrial chemical primarily used in the production of polyacrylamide and as a chemical intermediate in the synthesis of a variety of other chemicals. The discovery of acrylamide in a variety of human foods including heat processed starchy foods such as potato chips and bread has been reported. Acrylamide have reproductive toxicity (4) neurotoxicity (3) clastogenicity (26), and mutagenicity in somatic and germ cells (27) It is also a toxicant of the male reproductive system in rodents, but very little evidence is available about its toxic effects on the female reproductive system (28) The toxicities of Acrylamide in male animals include degeneration of the epithelial cells of the seminiferous tubules, decreased number of sperm, and increase abnormal sperm and result in decreased fertility rates and retarded development of pups, as well as decrease levels of sex hormones (29). It promotes biological oxidation both in vitro and in vivo because of its pro-oxidant activity (30) Testicular oxidative stress appears to be a common feature in much of what underlies male infertility, which suggests that there may be benefits to develop better antioxidant therapies for relevant cases of hypospermatogenesis (31). The present study aimed to investigate protective effects of local propolis extract on testicular toxicity of acrylamide in male albino rats. To our knowledge this is the first study that evaluate the protective role of local propolis extract on testicular damage induced by acrylamide in experimental animals. Sperm characteristics as sperm concentration , motility, rate of viability, normal and abnormal sperm count considered as an important factors for the identification of the normal function of the testes (32).the present results showed that oral administration of acrylamide $(150 \mathrm{mg} / \mathrm{kg} \mathrm{B.W})$ cause highly significant reduction in the sperm parameters compared with control group rats, this result confirmed other pervious studies, where acrylamide use was associated with decreased sperm count motility $(\%)$, rate of viability (\%) and increased dead and abnormal sperm count $(33,34,35)$ this reduction in the sperm parameters may be ascribed to lowering in the serum testosterone levels which induced by acrylamide uptake which leading to degeneration of seminiferous tubules with sloughing of seminferous epithelium and spermatogenic cells (36) adequate level of testosterone in testes is critically required for normal spermatogenesis, maintenance of sperm morphology and normal physiology of somniferous tubules (37) Coadministration of local propolis extract to acrylamide treated group rats restored the sperm characteristics towards normal values which may be returned to restored in the serum testosterone levels which reflect positively on the sperm characteristics (38) in addition to anti-oxidative effectiveness of propolis mainly its flavonoids and phenolic content that is capable of scavenging free radicals and thereby protective against lipid peroxidation which can be produced by acrylamide (39). Such improvements in the semen characteristics by propolis collected from different region agree with previously reported benefits of propolis supplementation of sperm quality and male fertility of rats $(39,40)$. On the other hand, our results indicated that administration of acrylamide alone induced significant reduction at $(\mathrm{p}<0.05)$ in the absolute weights of testes and accessory reproductive organs ( epididymis, prostate and seminal vesicle ) compared with control group rats, this can be occur due to diminishion in number of germ cells , atrophy of leydig cells and lower 


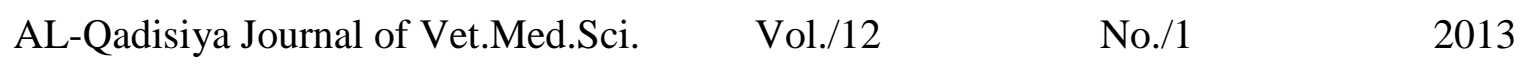

rates of spermatogenesis, because weight of the testes largely depends on the mass of the differentiated spermatogenic cells. Memorably, testicular mass is a valuable index of reproductive toxicity in male animals ( 41 ) decrease in this parameters was consistent with elimination of germ cells ( 42 ) So co-administration of local propolis extract to acrylamide treated rats restored the testes weights and other reproductive organs towards normal which may be returned mainly due to antioxidant activity of propolis extracts ( 43 ) Testosterone consider as a key hormone that play important role in the regulation of spermatogenesis. Acrylamide administration induced significant decrease at $(p<0.05)$ in levels of serum testosterone and other studied hormones ( FSH , LH ) compared to control group rats Whereas it was found that co-administration of local propolis extract cause significant differences as compared with untreated acrylamide group rats, this give indicator that propolis extract hence testosterone hormone and FSH, LH production and ameliorate sperm production and the process of fertility. The role of propolis on the testosterone and other reproductive hormones has been reported. In previous study performed on the Turkish awassi lambs at weaning time, demonstrated that the administration of the Iraqian propolis watery extract cause significant elevation in the levels of serum testosterone, FSH and LH compared with control group lambs (44). From the results of present study can be concluded the important role of local propolis extract in protection of male reproductive organs from detrimental effects of acrylamide in male albino rats and minimize its reproductive toxicity.

\section{References}

1. Isidori A.M.; Gianfrilli,C and Isidori,A. .(2006).medical treatment to improve sperm quality .J. Reprod.Biomed , 12:704-714.

2. Alurfan,E.;Becren,A.;Sehirli,A.;Demiralp ,Z.;Sener,G. and Omurteg, G. (2012). Protective effect of $\mathrm{N}$ acetyl-L-cysteine against acrylamide -induced oxidative stress in rats. Turk. J. Vet. Anim.36:438-445.

3. LoPachin, R.M.; Balaban, C.D. and Ross, J.F. (2003). Acrylamide axonopathy revisited. Toxicol Appl.Pharmacol. 188:135-153.

4. Telebi,A.R.;Anvari,M.A;Pourentezari,M.; Khalili,M.and Mangoli,M. (2012). Effect of acrylamide in presence of vit.E on sperm parameters \& testosterone hormone in mice.New York Sci.J.5(9):69-74.

5. Johnson, A.; Gorzinski, K. and Bodner, K.M. (1986). Chronic toxicity and oncogenicity study on acrylamide incorporated in the drinking water of Fischer 344 rats. Toxicol. Appl. Pharmacol. 85: 154-168.

6. Crane,E.(1997). The Past and Present Importance of Bee Products to Man.Bee Products: Properties, Applications, and Apitherapy. Plenum,New York .

7. Salatino, A.; Teixeira, E.W.; Negri, G.; Message, D.(2005). Origin and chemical variation of Brazilian propolis. Evidence-based Complementary and Alternative Medicine 2: 33-38.

8. Marcucci,M.C. ; Ferreres,F. ; CustodioA.R.; Ferreira,M.M V.S. Bankova, C. and Garcia-Viguera, W.A.(2000). Bretz Evaluation of phenolic compounds in Brazilian propolis from different geographic regions Z. Naturforsch. 55: 76-81.

9. Ahn, M.; Kumazawa, S.; Usui, Y.; Nakamura, J. and Matsuka, M. Zhu,F. .(2007).Antioxidant activity and constituents of propolis collected in various areas of China Food Chem., 101 :1400-1409 
$\begin{array}{llll}\text { AL-Qadisiya Journal of Vet.Med.Sci. } & \text { Vol./12 } & \text { No./1 }\end{array}$

10. Çikrikçi, S.; Mozioğlu, E. and Y1lmaz.H.(2008). Biological activity of curcuminoids isolated from Curcuma longa. Rec. Nat. Prod.12: 19-24

11. Sforcin,J.M.(2007). "Propolis and the immune system: a review .J> of Ethnopharmacol. 113: 1-14.

12. Nakamura, R.; Nakamura, R.; Watanabe, K.; Oka, K.; Ohta, S.; Mishima, S. and Teshima, R.(2010). Effects of propolis from different areas on mast cell degranulation and identification of the effective components in propolis. International Immunopharmacology, 10: 11071112.

13. Vatansever, H.S.; Sorkun, K.; Gurhan, S.I.D.; Ozdal-Kurt, F.; Turkoz, E., Gencay, O. and Salih, B., (2010). Propolis from Turkey induces apoptosis through activating caspases in human breast carcinoma cell lines. Acta histochemica 112 : 546-556.

14. Ghisabert,E.L.(1979).Bee propolis.Bee World.60:59.

15. Usia, T. Banskota, Y. Tezuka, K. Midorikawa, K. Matsushige, S. Kadota, J.(2002). Constituents of Chinese propolis and their antiproliferative. Nat. Prod. 65: 673.

16. Burdock,G.A.(1998). Review of the biological properties and toxicity of bee propolis . Food Chem. Toxicol. 36 (1998) 347.

17. Banskota, A. Nagaoka, T. Sumioka, L.Y. Tezuka, K. Awale, K. Midorikawa, K. Matsushige, K. Kadota,S.(2002). Studies of the constituents of Uruguayan propolis.Ethnopharmacology. $\quad 80$ (2002) 67.

18. Song, Y.S.; Park, E.H.; Hur, G.M.; Ryu, Y.S.; Lee, J.Y.; Kim, Y.M. and Jin, C., (2002). Caffeic acid phenethyl ester inhibits nitric oxide synthase gene expression and enzyme activity. Cancer Letters, 175: 5361.

19. Bearden, J.H. and Fluquary, J.W. (1980). Applied animal reproduction. Reston,VA: Reston Publishers. p.157-169.

20. Miller P.G. and Pass N.P. (1952). Manual of infertility and artificial insemination in cattle. Biolliere Tindall and Cox, London, U.K. p: $29-35$.

21. Okamura, A., Kamijima, M., Shibata, E., Ohtani, K., Takagi, K., Ueyama, J., Watanabe, Y., Omura, M., Wang, H., Ichihara, G., Kondo, T. and Nakajima, T. (2005). A comprehensive evaluation of testicular toxicity of dichlorvos in wistar rats. Toxicology. 213, 129 137.

22. Teitz, N. W. (1995) . Clinical Guide to Laboratory Tests. 3rd ed., Philadelphia,W.B. Saunders Co., P. 578.

23. Bankova V.S.; Castro D.S.L and Marcucci, M.C. (2000). Propolis: recent advances in chemistry and plant origin. Apidologie, 31: 3-15.

24. Banskota, A.H.; Tezuka, Y. and Kadota, S.( 2001). Recent progress in pharmacological research of propolis. Phytotherapy Research. 15:561-571.

25. Russo, A. Troncoso, N. Sanchez, F. Garbarino, J. Vanella,A. .(2006).Propolis protects human spermatozoa from DNA damage caused by benzo[a]pyrene and exogenous reactive oxygen species Life Sci. pp. 1401-1406

26. Ghanayem BI, McDaniel LP, Churchwell MI, Twaddle NC, Snyder R, Fennell TR, and Doerge DR (2005a). Role of CYP2E1 in the epoxidation of acrylamide to glycidamide and formation of DNA 
$\begin{array}{llll}\text { AL-Qadisiya Journal of Vet.Med.Sci. } & \text { Vol./12 } & \text { No./1 }\end{array}$

and hemoglobin adducts. Toxicol

Sci 88:311-318.

27. Ghanayem BI, Witt KL, El-Hadri L, Hoffler U,Kissling GE, Shelby MD, and Bishop JB (2005b). Comparison of germ cell mutagenicity in male CYP2E1-null and wild-type mice treated with acrylamide: evidence supporting a glycidamide-mediated effect. Biol Reprod 72:157-163.

28. Tyl, R. W., and Friedman, M. A. (2003). Effects of acrylamide on rodent reproductive performance. Reprod. Toxicol. 17, 1-13.

29. Tyl, R. W., Marr, M. C., Myers, C. B., Ross, W. P., and Friedman, M. A. (2000). Relationship between acrylamide reproductive and neurotoxicity in male rats. Reprod. Toxicol. 14, 147-157.

30. Yousef, M.I. and El-Demerdash, F.M. (2006). Acrylamide-induced oxidative stress and biochemical perturbations in rats. Toxicology 219, 133-41.

31. Yousef, M.I., El-Demerdash, F.M. (2006). Acrylamide-induced oxidative stress and biochemical perturbations in rats. Toxicology; 219: 133-141.

32. U.S. Enviromental Protection Agency (EPA) (1996). Guidelines for reproductive toxicity risk assessment. Federal Register (part II). Vol. 61, 212: 56272- 56322. From the Federal Register online via GPO Access [http://wais.access.gpo.gov] (internet).

33. Sakamoto,J.; and Hashimoto, K. (1988). Effect of N,N methylene-bisacrylamide on mouse germs cells sperm count and morphology and testicular pathology. Arch. Toxicol. 62:54-59.

34. Wang,H.;Huag,P.;Lie,T.;Hutz,R.andShi, F.(2009).Reproductive toxicity of acrylamide - treated male rats.Reprod.Toxicol.29:225-230.

35. Rashagale,S.;Janqir,B.;Patil,M.;Verma, T.;Bhandarkar,A.; and Kurkure, N. (2012).Evaluation of protective effect of vit.E on acrylamide induced testicular toxicity in wister rats. Toxicol. Int.19:158-161.

36. Yang, H.J; Lee, S.H.; Jin, Y.; Choi, J.H.; Han, C.H. and Lee, M.H.(2005). Gentoxicity and toxicological effects of acrylamide on reproductive system in male rats.

J Vet Sci .6:103-9.

37. Sharpe, R.M. ; Donachie, K. and Cooper, I. (1988). Reevaluation of the intratesticular level of testosterone required for quantitative maintenance of spermatogenesis in the rat. $J$ Endocrinol. 117: 19-26.

38. Shalaby,K.A. and Saleh,E.M.(2011). Ameliorative Effect of Honey Bee Propolis on the Nonylphenol Induced- Reproductive Toxicity in Male Albino Rats.Australian Journal of Basic and Applied Sciences, 5: 918-927.

39. Yousef, M.I.and Salama, A.F. (2009).Propolis protection from reproductive toxicity caused by aluminium chloride in male rats. Food Chem. Toxic., 47: 11681175.

40. Yousef ,M. ;Kamel , I.;Hassan,M. and El-Morsy,A.(2010). Protective role of propolis against reproductive toxicity of triphenyltin in male rabbits. Food Chem. Toxic., 47: 1846-1852.

41. Aman RP. (1982). A critical review of methods for evaluation of spermatogenesis from seminal characteristics. J Androl. 2:37-38.

42. Chapin RE, Lamb JC. (1984). Effect of ethylene glycol monoethyl ether on various parameters of testicular 
$\begin{array}{llll}\text { AL-Qadisiya Journal of Vet.Med.Sci. } \quad \text { Vol./12 } & \text { No./1 }\end{array}$

function in the F344 rats. Environ Health Perspectives. 57:219-224.

43. Miguel,M.G.;Nunes,S.L.;Bandlen,S.A. and Antunes,M.D.(2010).Phenols and antioxidant activity of hydroalcoholic extract of propolis from
Algarve, south of Portugal. Food and Chem.Toxicol.48:3418-3423.

44. Hussien,H.K.(2011).Effect of propolis extract on past-weaning LH,FSH and testosterone concentration in Turkish Awassi lambs.J of Anbar. Vet.Sci.4:219-224.

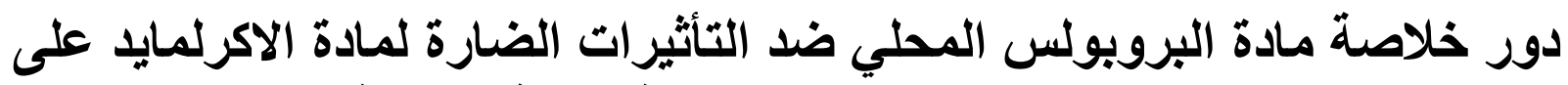 بعض معايير الجهاز التتاسلي الأكري في الجيلي الجرذان
}

\author{
علي محمد غازي حسن خلف عليوي سلم سلم حسين جاري \\ كلية الطب البيطري / جامعة القادسية
}

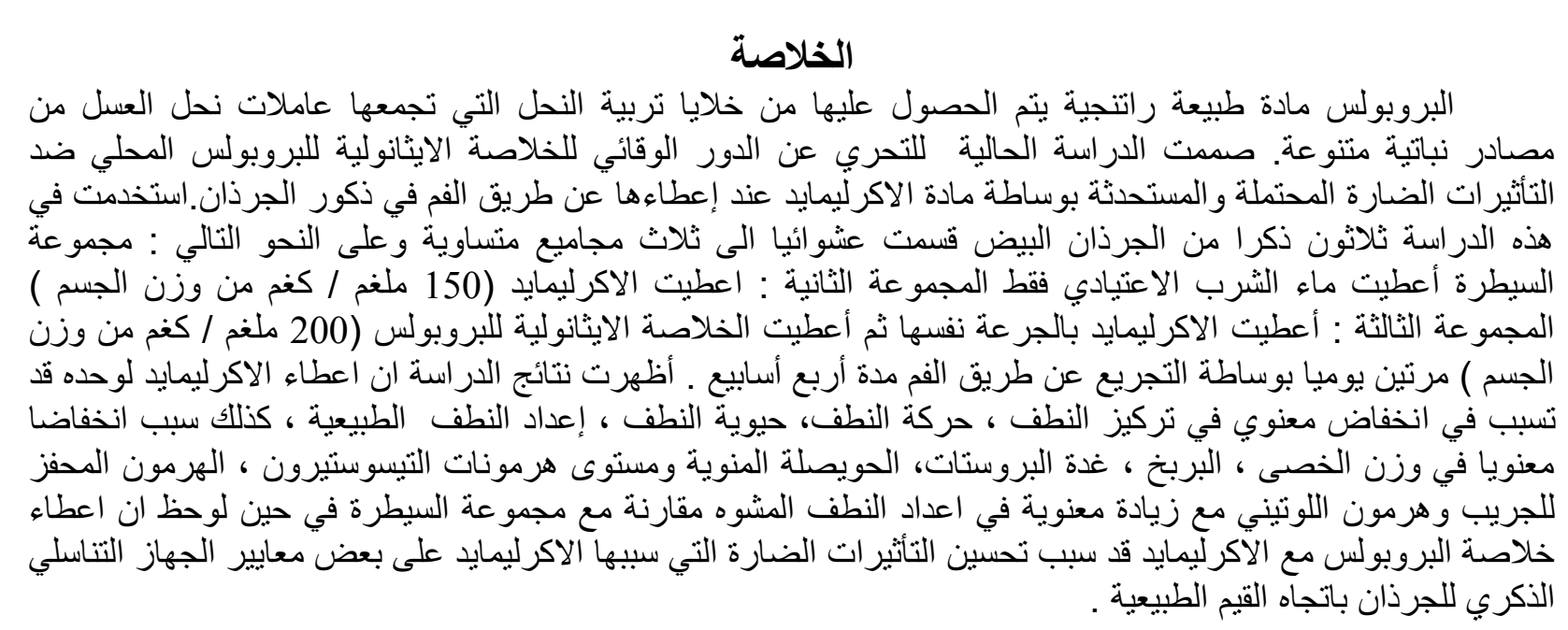

